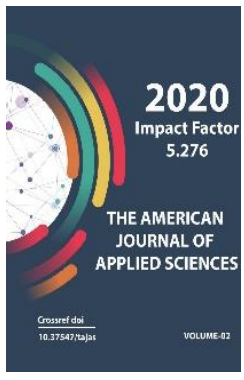

Journal Website: http://usajournalshub.c om/index,php/tajas

Copyright: Original content from this work may be used under the terms of the creative commons attributes 4.0 licence.

\section{Environmental Tourism: Its Status And Future Prospects In Uzbekistan}

Nigmatov Askar Nigmatullaevich

Doctor Of Geographical Sciences, Professor. Department Of "Geodesy, Cartography And Natural Resources", Karakalpak State University Named After Berdak, Uzbekistan

Imomov Sanjar Mukhamadievich

Chief Specialist Of The Department For The Development Of Ecological, Agrotourism, Sports And Medical Tourism Under The State Committee For Tourism Development Of Uzbekistan

\title{
ABSTRACT
}

The article reveals the fundamental theoretical basis of ecotourism. Through accurate data, on the example of the Republic of Uzbekistan, its current situation is analyzed and proposals for future prospects are made.

\section{KEYWORDS}

Tourism, ecotourism, concept, purpose, functions, object, subject, directions, Uzbekistan, status, future occupation, recommendations.

\section{INTRODUCTION}

One of the areas of tourism, which is developing in the structure of the tourism industry in an accelerated fashion, is "ecological tourism" or "ecotourism"(figure
1). This term is a science, education and practice, which consists of the sum of two terms.The term ecology is formed from a combination of words in the Greek language 
oikos-House, place of residence, more precisely the place of residence, logosdoctrine. The term"tourism" in French means tourisme-travel, recreation, as well as sports and the performance of universal or politicaleducational tasks.

In a narrow sense, both terms are generalized ecological tourism (ecotourism) - the travel of people to the environment in which organisms live.

In a broad sense, ecological tourism is the ability of individuals to relax from their permanent places of residence, to engage in sprot, to be healthy, to carry out educational and spiritual (universal) work, or to travel to natural objects with the aim.

The subject of environmental tourism, or its participants, can come out both physical and legal entities. According to civil law, individuals are citizens of a particular state, foreign citizens, stateless persons. According to Article 50 of the Constitution of Uzbekistan, all citizens, including those engaged in tourism, are obliged to treat the environment with caution to the natural environment. Tourist movements of individuals are characterized by the fact that in most cases they pass spontaneously, that is, they have a certain organizational and managerial capacity. According to data, individuals who are engaged in environmental tourism are 3-4 times more likely to damage the natural environment than the legal entities. Birigina has raised 13-16 million dollars per day to nature through "free" holistic tourists in Louisiana, USA. dollar thalophate is being brought. Local government agencies as an environmental measure it is allowing individuals to be forced into "environmental certification" and "environmental insurance".

The unlike a person, a legal entity, a tourist organization under its own status, having a special permit, carrying out the corresponding expenses related to 


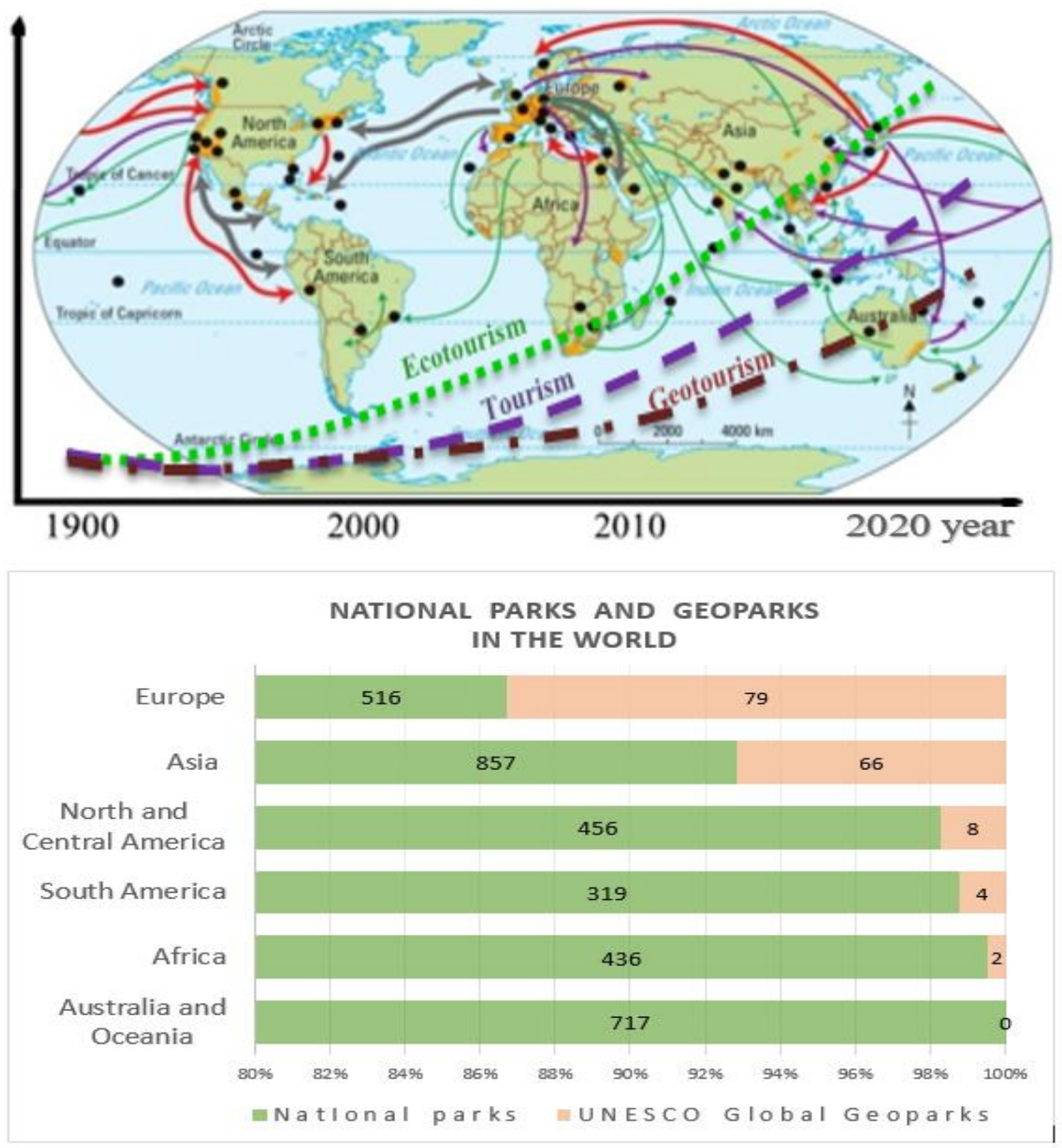

1- figure. Tourism in the world, including the development of ecotourism and geotourism

Tourism in the balance and estimate, is considered a person who is able to respond to negative environmental consequences with his property or be a plaintiff. In other words, state, non-governmental and self-governing bodies are participants in environmental tourism, which is characterized by a high degree of opportunity to manage and regulate, and are considered legal entities. Therefore, the development of environmental tourism in the status of a legal entity with special training and responsibility in the future is one of the main tasks of the international community, state and society. 
More than 30 companies adapted to ecotourism are operating in Uzbekistan: the state branch of development of Uzbekistan, The state branch of Ecology and Environmental Protection, the state branch of Forestry, The State geological and mineral resources, as well as the Federation of ecotourism, the Federation of extreme and mountaineering, the Society of geography and on this day more than 30 companies are operating Together with them, it is desirable to organize responsible trips to the beautiful natural places of our republic,

to acquaint our citizens with the nature of our country, to develop normative documents, regulations, programs, recommendations for the development of ecotourism and direct their efforts for their implementation.

In this place, it is necessary to clarify two issues. What kind of efforts of those is exactly tourism. Tourism is the departure (travel) of an individual from a permanent place of residence without engaging in activities related to the receipt of income from sources in the country (place) of temporary stay. A tourist is a natural person who travels to the country of temporary stay (place) for a period of twenty-four hours to twelve months in a row, without engaging in activities related to the receipt of income from sources in the country of temporary stay (place), or who spends at least one night in the country of temporary stay.

Ecotourism is a responsible journey that is carried out with the aim of socio-economic support of nature-protected objects and territories, increasing the awareness of the local population, forming their knowledge and understanding about nature . But since ecotourism is a relatively new field of Science, a direction of education and a network of Economics, its theoretical and practical bases have not yet been created in the world. Ecotourism is interpreted differently by different countries, international organizations and specialists. As a result, it is difficult to find accurate statistical information about it, the target, that is, pure environmental conceptions of national, regional and global development have not been developed, relevant programs and plans have not been adopted.

\section{MATERIALS AND METHODS}

Thus, ecotourism is the travel of people from places of their permanent residence in an ecological direction (in character) that they do to the surrounding nature or to certain natural objects, while pursuing goals such as recreation for a certain period of time, playing sports, performing health, educational and spiritual activities. Its tourist object is ecosystems. And the goal is tourism, aimed at protecting ecosystems, rational use of natural resources of ecosystems and the restoration of degraded natural systems (figure 2).

In this regard, we should particularly note that ecotourism is a tourism in the style that pursues environmental goals. After all, it is not at the required level of targeted actions that reflect its original content and essence when organizing various ecotouristic companies, when developing Ecotours and bringing them to the tourist market, when making tax and duty payments, when developing plans and programs. With ecotourism, natural tourism, sports tourism, agroturism, geotourism, rural tourism are mixed.

With ecotourism, natural tourism, sports tourism, agroturism, geotourism, rural tourism are mixed. With ecotourism, individuals between the ages of 35-54, (usually $80 \%$ of students, mostly $50 \%$ of women and $50 \%$ of men), most of them are regular tourists, interested in Nature Conservation and willing to spend more. According to the FAO, ecotourists in many ways differ from ordinary tourists in that they travel a long distance; length of days of stay; aspiring to physical 
movement and innovation; are distinguished

by the nature.

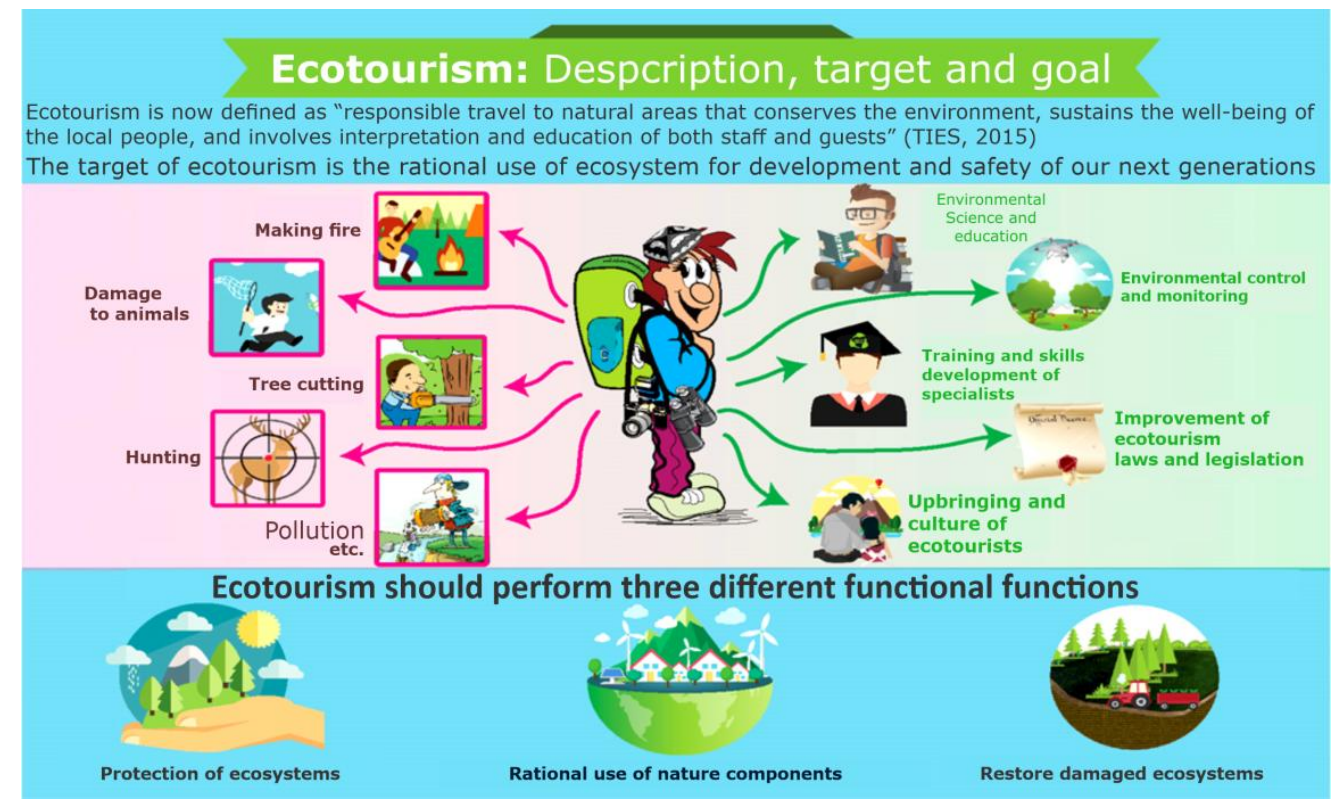

Figure 2. The concept, purpose and functions of ecotourism

Worldwide, the share of the travel and tourism industry in Yaim for the years 20002019 is on average from 9,3 to 10.9 percent, and in the years 2020-2029 is directly $\$ 5,5 \mathrm{trl}$. and the total contribution is $\$ 18 \mathrm{trl}$. It is predicted to be on account of the US dollar. The growth rate of ecotourism is 2-3 times higher than the growth rate of the general tourism industry. Ecological tourism is one of the new directions of modern tourism, and now the tourist flow, unlike the twentieth century, is changing from developed countries to developing countries. According to data, in the year 2020, 10 percent of the market was occupied by the year 2019, covering 35 percent of the market. According to a consumer survey conducted by the International Organization for tourism, as a result of climate change, beaches ecotourism welcomes travel, because most of the benefits derived from ecotourism are focused on environmental and local population extravagance goals. As an example, in addition to the fact that sustainable tourism is developing in the countries of Malaysia, Thailand, China and Turkey, it is also evident that tourists are under pressure from the visit to the ecosystem.

Ecotourism environmental instruments and restore activation strengthening "quality". Ecotourism following nature will meet directly, bukhariy by of feel Atisha, nature coined fol ladies Oles and egotisitical nemili man for big value profession these englisha direction.

Ecotourism is an inherently deprived component or uning-an external unbroken component. Kishilarning she nature objeclive kirilgan tourism ecotourism Kirillov. The natural essence of an 2 cutter object that can be described: 
1)Monuments of nature (waterfalls, caves, trees and their compositions, rare species of flora and fauna, underground treasures and finds, Stones of a specific form, etc.) that are relatively untouched or unchanged and have not lost the character of their natural origin.the G.), natural elements and rocks, such as landscapes, water aquatoriums, land surface, atmospheric layer. These include areas that are mainly protected separately by the state, such as biosphere reserves, reserves, order reserves, national natural parks, and areas that are "Absolut" of the state.

2) Monuments of nature, changed as a result of people's activities (anthropogen) or natural processes and phenomena (disasters). These include more than three hundred geographic objects, quarries, techno-ruined lands, cut and burned forests, ravines, surges, lungs. This place can be cited as the largest object of ecotourism, as an example, the Aral Sea and the surrounding ruined territories.

In general, for the object of ecotourism, each object of tourism must meet the following requirements::

- The fact that organisms have a place or place of residence, that is, they do not leave the biosphere circle;

- Have changed or not changed due to natural origin;

- The possibility of staying on the beaches for more than 24 hours or staying at night;

- Participation in the exchange of substances and energy in environmental systems.

The subject of ecological tourism is tourism of an ecological nature.

This means that tourism is aimed at protecting the natural environment of the environment and preserving it, restoring the damaged nature unsurlari andeksexs, rational and effective use of Natural Resources.
The purpose of ecotourism is the rational use of nature in the tourist direction in order to ensure the ecological safety and sustainable development of the present and future generations. In order to realize the purpose of ecotourism, international organizations and national sources of legislation require us to carry out the following tasks:

$\checkmark$ Development of special laws for the formation of the ecotourism industry and the creation of their legal framework;

$\checkmark$ Development of theoretical foundations of ecotourist Science, Education and practice;

$\checkmark$ Raising the environmental consciousness and culture of the population through ecotourism;

$\checkmark$ Establishment of education and training in the direction of ecotourism;

$\checkmark$ Solution of issues of social protection of local population of eco-tourism;

$\checkmark$ Training and retraining of specialists in ecotourism;

$\checkmark$ Comprehensive evaluation of ecotouristic objects and their cadastre;

$\checkmark$ To establish monitoring and perspective of ecotourism;

$\checkmark$ Zone of the territory of our country on ecotourism;

$\checkmark$ Establishing the activities of types of tourism by legal entities and physical persons engaged in ecotourism and establishing measures to support them in legal terms;

$\checkmark$ Develop tactical plans and strategic programs and plans for ecotourism of states and the international community;

$\checkmark$ Create a ome that encourages positive actions on ecotourism;

$\checkmark$ To impose economic liability sanctions against environmental offenders;

$\checkmark$ Conservation of Biological diversity, etc.k.

1. "Today, - said the president of the Republic of Uzbekistan Islam Karimov, the problems of environmental security, the proper establishment of natural 
relations with man in the 21st century kiss are more pressing than ever. After all, the solution of this problem is in the interests of all peoples, the bug and the future of world civilization in many ways are connected with it."

2. The performance of the above tasks is considered one of the most alternative ways to ensure the environmental rights of people. Think for yourself, a lot of talk about the shortage of water and land in Uzbekistan and their preservation

3. And the animations displayed may not always lead to the expected results. Therefore it is necessary that our wise people

4. "The one who saw a stage better than the one who heard the face," says. Through ecotourism, humans make appropriate independent decisions, discuss with others, consider and compare the nature of the environment in which they live. In the laconic words "seeing one makes thanks and thinking seeing. Environmental tourism also has enormous opportunities to educate people who are environmentally conscious and cultured who are exactly thinking and expressing gratitude, and to spend their profits from tourism for the restoration of degraded or degraded natural objects. Only, it is desirable that these actions are scientifically based and based on the recommendations that have been verified in practice.

5. In carrying out these tasks, it is necessary to comply with the following ecotouristic, that is, rules aimed at regulating environmental relations through tourism:

6. Priority of issues of nature protection and sustainable development in ecotourism. This means that at least 24 hours of trips that people are making to nature, at least 30-35 percent of the revenue from environmental protection, rational use of Natural Resources, should be directed to the regulation of ecological relations and the restoration of broken nature complexes, that is, it should be of environmental importance.

7. The fact that ecotourism is inextricably linked with other types of tourism, such as historical, cultural, religious tourism. This means that it is better to visit historical monuments (for example: Samarkand, Bukhara, Khiva), which are now well established, to visit cultural and religious holy places

8. (Religious objects such as the Registan ensemble, at-Termiziy, Al-Bukhari and Khoja Ahmad Yassavi), along with tourism types such as cruising and visiting, set out to take ecotouristic routes.

9. The obligation of ecotourist in all educational institutions of the direction of Tourism and service. Also on this day is the obligation of ecotourism education in all educational institutions of the direction of Tourism and service. This means that 10 colleges under the Ministry of Tourism Development, 2 Technical Universities and the International University of Tourism"Silk Road", as well as in educational institutions related to tourism (Samarkand Institute of Economics and service, Tashkent University of Economics and diplomacy, Singapore Institute of management development in Tashkent, Tashkent State Agrarian University, Children's centers of the generation of harmonious under the ministry", Development of programs and plans, creation of educational literature and their implementation in the educational process (such as" ecotourism service"," ecotourist kid", "marketing and promotion", "local economy", environmental education).

10. The fact that eco-hazardous and degraded nature komplexs are also an ecotouristic object. This means that trips to specially protected areas, such as the ruined and crisis nature complexes (the 
Aral Sea and its environs, the territories under the influence of the Turzunzadeh aluminum plant, the regions such as Chernobyl, Almalyk and Uchkuduk industrial districts) or a reserve with a unique landscape appearance, the order reserve, the National Garden, the Natural Reserve, raise tourists' environmental awareness and culture, teach them

11. The rational use of nature and the content of conservation of nature is a unified system of local, regional and global Ecotourism. Every tourist firm or individual should feel responsibly to tourists that the activities they carry out on ecological routes are not only their neighborhood, but also their sacred duty before the state, society and the international community.

12. Of immense importance in the sustainable development of ecotourism in the cultivation of environmental consciousness and culture of the local population. It is necessary to prove to the population that the development of the ecotourism industry at the local level can be carried out directly through ecotourism, by understanding that the increase in the income of the people living here can lead to both economic and social protection and the preservation of their living space.

13. Environmental tourism in the state, society, local government bodies. Environmental tourism in the state, society, local government bodies.This means that ecotourism is at the same time one of the main means of bringing additional income to the state and the population, reducing poverty and introducing Uzbekistan to the world, the regulation of Public Relations.

14. Ecological-socio-economic viability in ecotourism. Ecotourism is not only to take advantage or keep the population busy with work, but also to remember that they perform vital functions, such as restoring their health, living a healthy life.

15. The need for the formation of national pride and pride in ecotourism. Traveling to the Bay of nature, increasing the population's love for their country, Homeland, instilling in them a sense of patriotism, that is, the absorption of the requirements of a national idea.

\section{DISCUSSION AND RESULTS}

In order to attract tourists to the nature, unique flora and fauna of Uzbekistan, it will be necessary to solve organizational and legal issues for the implementation of the abovementioned ecotouristic prints.

The Department of bio-health and ecotourism was opened in the State Department of Ecology and Environmental Protection of the Republic of Uzbekistan. Buxoro specialized gazelle pitomnigi $16522 \mathrm{~km} 2$ hectare area, for the development of ecotourism in the nursery, a scientific and economic-based program on the conservation and reproduction of low-flying noyo6 pairs of ungulate animals (Gazelles, buxoro sheep, Buxoro bug, morhur) in Central Asia was approved. The program of ecotourism, recreation and agroturism is being developed in the system of Aydar-Arnasoy lakes located $65 \mathrm{~km}$ northwest of the city of Jizzakh. In 2000 hectares (Hazrati Sultan plateau, Suvtushar waterfalls and dinosaur tracks and Amir Temur cave), which were transferred from the territory of Hisar State Reserve to its reserve zone in kashkadarya region, were transferred from the Reserve zone to its reserve zone for ecological tourists.The Cabinet of Ministers of the Republic of Uzbekistan approved the program "development of ecotourism in some protected natural areas of the Republic of Uzbekistan (4 national nature parks, 6 state order reserves, all monuments of nature)" on 
August 5, 2020 with the number 05/1-3553. Also, the status of the book geology reserve the book is planned to become the National Nature Park of Geology and include it in the list of UNESCO geo parks in keljak. As such, the forest sector is selected as potential farms for the development of ecotourism in specialized Forestry such as Bobotogh, Uzun district, Kitab, Shahrisabz, Yakkabag, Bakhmal, Zomin, Jondor, Khorezm, Kokand, Burchmulla and Pop in the state agricultural system.

In general, Uzbekistan is one of the leading countries in Central Asia in terms of its tourist resources potential, and in the world it occupies a high place in 10-15 countries. On the territory of the Republic there are more than four and a half thousand monuments of architecture, history and natural origin in different geological and social periods. Think for yourself that now in Uzbekistan there are unique beautiful nature, landscapes, unique flora and fauna, archaeological finds with a rare World Heritage, paleontological remains, Geological incisions that are rare in the world, which can attract the attention of citizens and foreign tourists.

According to the State Department for Ecology and Environmental Protection, the biodiversity of the Republic of Uzbekistan consists of more than 27000 species. For example, more than 8000 natural monuments, 38 million. more than hectares of hunting and fishing land, 206 species of animals listed in the Red Book Of The Republic of Uzbekistan, 314 species of plants, 32 species of mammals, 52 species of birds, 21 species of reptiles, 18 species of Fish and 83 species of invertebrates are just three of us. 4 national parks 555154 km², 11 natural monuments 3760 km², 12 state order Reserve 572404 km², 2 Biosphere Reserves $111670 \mathrm{~km}^{2}$, Bukhara specialized Gazelle pitomnigi16 $522 \mathrm{~km}^{2}$ and Saygachi lanshaft order $62830 \mathrm{~km}^{2}$, 7 State Reserve (Hisar, Zaamin, Surkhon, Nurota, Kyzylkum State Reserve) 62830 km2, 7 State Reserve (Hisar, Zaamin, Surkhon, Nurota, Kyzylkum State Reserve) chotkol state Biosphere Reserve, saykhun state biosphere reserve) area $186335 \mathrm{~km}^{2}, 2020-2022$ for the years additional 5 units in the command system is organized. All this is $1508675 \mathrm{~km}^{2}$ or $3.4 \%$ of the territory of Uzbekistan (Figure 3).

According to the state agency for the development of Tourism, Uzbekistan received 2.7 million from abroad in 2017,5.3 million from abroad in 2018. In 2019 year

6.7 million. tourists $(85,4 \%$ came from Middle Asian countries to travel, trade and see relatives, $7,3 \%$ came from CIS countries and $7.2 \%$ from other countries. However, our country's capacity is at least 30 million. equal to tourists. In 2019, the contribution of tourist services amounted to only $0.6 \%$ of the gross national product. 


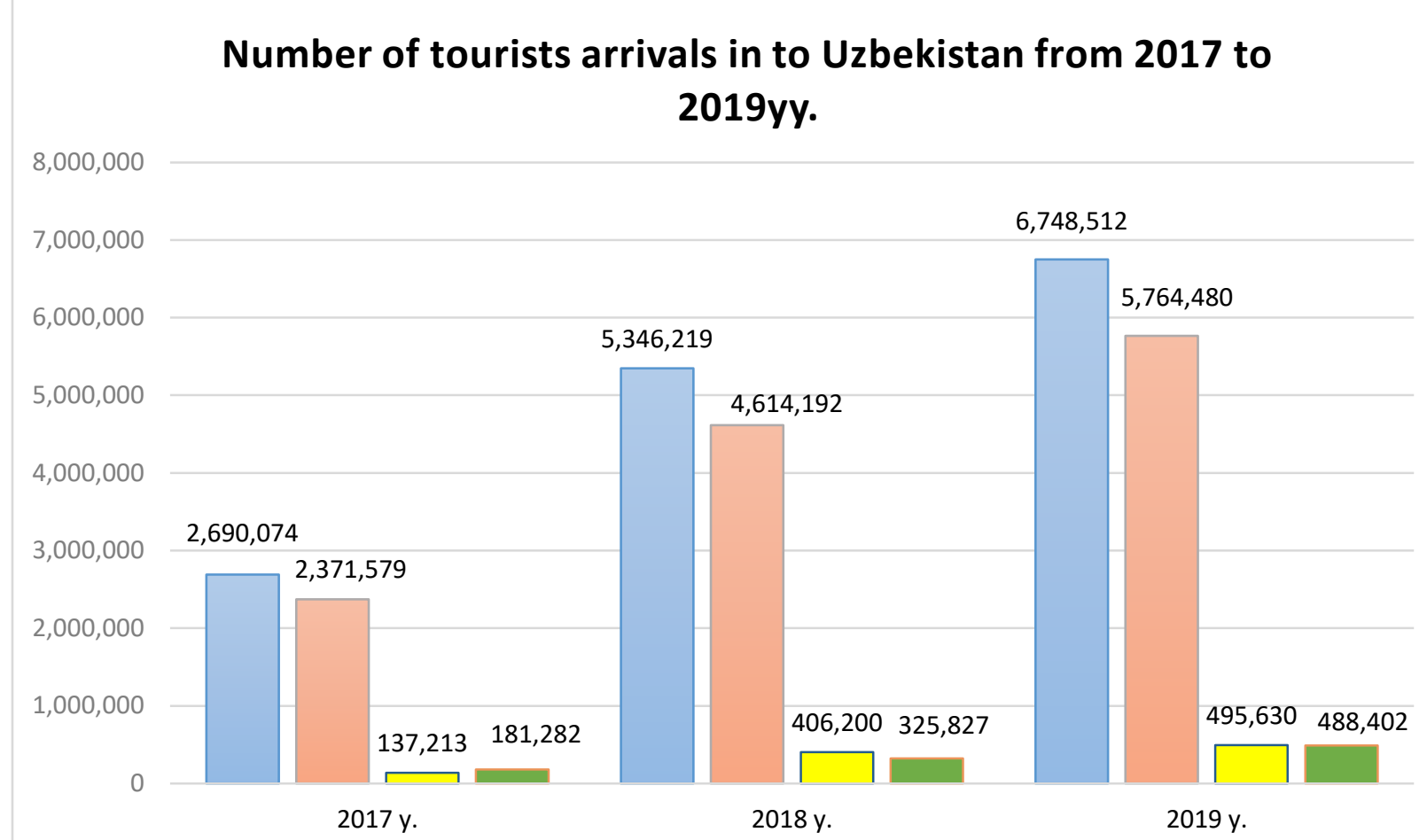

TOTAL number of tourists $\square$ Central Asian countries $\square$ CIS (other countries) $\square$ other countries

But is this organizational and legal framework adequate for the effective functioning of National Ecotourism? Of course not!ln our country, a single normative-legal document aimed at the development of ecotourism and attracting tourists has not been developed. Taking into account the rich ecotouristic opportunities of our country, it is desirable to issue a decree or a decree "on the state program of measures for the development of ecotourism in the Republic of Uzbekistan in 2020-2025"and to adopt the relevant decision of the Cabinet of Ministers. In the program, it is necessary to identify measures for the gradual development of ecotourism in our country, its implementation, material and financial resources, duration of implementation and responsibilities.As follows from the program, it is necessary to establish special departments and develop their regulations in the presence of the relevant state bodies.

Support for projects of non-governmental organizations engaged in ecotourism is required. In Uzbekistan, it is aimed to expand the various forms of property provision of ecotouristic services and to support entrepreneurial activity in it, as well as preferential lending, taxation of persons engaged in ecotourism, the release of products that are not possible to produce by ourselves in customs payments. For him, a comprehensive and in-depth analysis of the regulatory system of ecotourism, their improvement, the introduction of appropriate additions and changes, and the creation of the ecotourist-legal framework is a modern requirement. Individuals and legal entities engaged in ecotourism will need to develop model projects and business plans, create a 
database of material-technical, informationanalytical, operational services.

World experience shows that in order to develop ecotourism in our country, first of all, it will be necessary to establish ecotouristic science, education, upbringing and promotion. For this purpose, acceleration of scientific research on ecotourism, allocation of state grants on fundamental, practical and innovative projects and conducting competitions; coordination of scientific works; in order to prepare highly qualified personnel, it is necessary to consider the issue of entering special passwords (for example: "ecotourism management and business", "economy of ecotourism") in the composition of specialized councils of the Oak under the Cabinet of Ministers.

Professional College of such specialties as" ecotourist service"," ecotourist marketing and management"," ecotourism gidi"," local economy","ecological education", technical school, as well as in higher educational institutions, Bachelor's, master's, doctoral studies, that is, it is required to ensure the continuity of training of personnel in the relevant direction. It is necessary to develop state educational standards, model educational programs and plans on ecotourism, to create educational, educational and methodical literature, to improve the skills of personnel and to establish training of their retraining. In order to cultivate the ecotouristic consciousness and culture of the population, it is possible to organize in the media a special branch and series dedicated to ecotourism, conduct competitions, quizzes and, even more so, lottery games. It is desirable to publish scientific, popular publications (cards, booklets, atlases, calendars, etc.) dedicated to ecotourism, to increase their sites on the internet, social networks. Formation of ecotourism business. Breaking through ecotourism to national ideas and proud tourists is a very important issue.

\section{CONCLUSION}

The socio-economic issues of ecotourism are directly related to the employment of the population in the objects of ecotourism and the solution of the problems of their social protection, the creation of conditions for the development of small and medium-sized businesses. According to experts, as long as ecotourists are often composed of travelers who have a medium or high investment, provide a comprehensive. Because this type of tourism is very limited and expensive, even the revenue generated is more effective than Boka tourism.

Well, the development of National Ecotourism is one of the most urgent issues, and it is one of the factors that ensure the sustainable development of any state.

\section{REFERENCES}

1. Экология. Экология: русча-ўзбекча луғат. - Тошкент: «ЎМЭ» ДИН, 2012. 422424-6.

2. Туризм. Краткий словарь иностранных слов. - Москва: «Изд.иностр.и нац.словарей»,1958.- С.404.

3. Отчет Межправительственной комиссии по туризму.-Гаага,1989.-123 с.

4. Ўзбекистон Республикасининг “Туризм тўғрисида"ги қонуни, 2019й. ЎРҚ 549сон.3-модда.

5. Ўзбекистон Республикасининг “Туризм тўғрисида"ги қонуни, 2019й. ЎРҚ 549сон.3-модда.

6. https://www.responsibletravel.org/docs.

7. Нигматов А.Н. «Экотуризм ва унинг географик хусусиятлари» (Наманган вилояти мисолида). Монография. - Т.: «Наврўз» нашриёти, 2019. - 148 б.

8. https://news.un.org/ru/story/2011/09/1190 491 
9. https://www.statista.com/statistics/10999 33/travel-and-tourism-share-of-gdp .

10. https://www.statista.com/statistics/10934 86/travel-tourism-gdp-worldwideoutlook. 